Харківський національний університет міського господарства імені О.М. Бекетова DOI: $10.32347 / 2076-815 x .2019 .71 .261-270$

\title{
ОСОБЛИВОСТІ ПРОЕКТУВАННЯ ЕКОКВАРТАЛІВ
}

Розглянутий закордонний досвід формування екокварталів, виявлені етапи розвитку теорій $i$ практики формування екокварталів, визначені особливості та принциипи проектування кварталів: принции природо еквівалентності, біорегіоналізму, сочіальної справедливості та екологічності.

Ключові слова: екоквартали, зелені міста, екобудинки, принципи проектування.

Стан проблеми та її актуальність. На сучасному етапі розвитку суспільства для забезпечення сприятливого середовища проживання людини постає проблема узгодження темпів і характеру розвитку міського середовища 3 можливостями біосфери. У місцях найбільшої концентрації населення і виробництва, якими $\epsilon$ найбільші міста, багато важливих для людини властивостей екосистем втрачаються або значно деградують: чистота атмосфери, естетичні властивості ландшафтів, доступність природних місць відпочинку і т.д. В даний час ця проблема вирішується на основі концепції сталого розвитку населених пунктів, наслідком розвитку концепції $є$ поява в кінці 1980 рр. в різних країнах житлових екокварталів. Екоквартали - новий підхід до проектування, будівництва, територіального планування житлових кварталів в рамках циклічної економіки з максимальною рекуперацією енергії і вторинною переробкою відходів [1]. Однак у вітчизняній архітектурній теорії відсутні комплексні дослідження, які вивчають архітектурно-містобудівні особливості формування екокварталів.

Актуальність дослідження визначає також: необхідність реновації деградованих ландшафтів найбільших міст на територіях колишніх промислових підприємств; недостатність вивченості сучасних тенденцій формування екокварталів, відсутність досліджень та практики будівництва їх на території України; необхідність вивчення закономірностей формування екокварталів та апробації позитивного зарубіжного досвіду на території України.

Рішення проблеми в загальних рисах лежить у формуванні цілісного середовища житлових утворень, в якому як антропогенне середовище, так i 
соціальна спільнота мешканців здатні до самовідновлення і стабільного розвитку без нанесення шкоди природному середовищу.

Мета дослідження: виявлення методичних принципів та архітектурномістобудівних прийомів формування житлових екокварталів. Завдання дослідження: - аналіз наукового і практичного досвіду будівництва житлових екокварталів; - визначення особливостей формування та проектування екокварталів; - визначення прийомів і формулювання принципів формування житлових екокварталів. Об'єкт дослідження: житлові екоквартали. Предмет дослідження: закономірності архітектурно-містобудівної формування житлових екокварталів.

Межі дослідження: Типологічні межі дослідження визначаються комплексним розглядом особливостей проектування житлових кварталів на основі концепції сталого розвитку. Часові межі дослідження включають період від останньої чверті ХХ століття до сьогодення.

Методи дослідження: використовувалися загальнотеоретичні наукові методи - аналіз, систематизація, аналогія i синтез. На першому етапі дослідження використовувалися методи порівняльного та історичного аналізу проектування та реалізації екокварталів, аналізу літературних джерел. Особливості формування екокварталів виявлені 3 використанням методів порівняння, аналогії, систематизації і синтезу. Для аналізу ділянок екокварталів застосовувалися методи містобудівного передпроектного аналізу. При розробці аналітичних схем, а також схем проектного рішення використовувався метод графічної формалізації і моделювання.

Аналіз літературних джерел та останніх публікацій. Основу теоретичних узагальнень дослідження становлять існуючі об'єкти дослідження, проекти формування екокварталів закордоном [1-7]. Проаналізовані публікації й праці вітчизняних та закордонних дослідників (Тетіор А., Бартон Х. та інш.) [8-15].

Виклад основного матеріалу. У дослідженні вивчався практичний досвід будівництва житлових екокварталів в Бельгії, Німеччині, Англії, Італії, Греції [6-7], Росії та ін. країнах (рис.1-2). Найбільш відомими є такі екоквартали - Вобан у Фрайбурзі в Німеччині; Hammarby Sjöstad - екоквартал на місці занедбаної промзони в Стокгольмі (Швеція); еко-квартал Відейан (Vidailhan) в Тулузі, екоквартал Бусіко (Boucicaut), эко-квартал Монконсей (Monconseil), эко-квартал Клиши-Батиньоль (Clichy-Batignolles) та Ранжис (Rungis) в Парижі, Франція та ін. Аналіз закордонного досвіду показав, що у європейській практиці екоквартал $\epsilon$ частиною стратегій зеленого міста $[6,7,12,13]$, а житловий квартал має право називатися екокварталом, якщо дотримані наступні умови $[2,3,15]$ : 
• використання виключно екологічних матеріалів та методів;
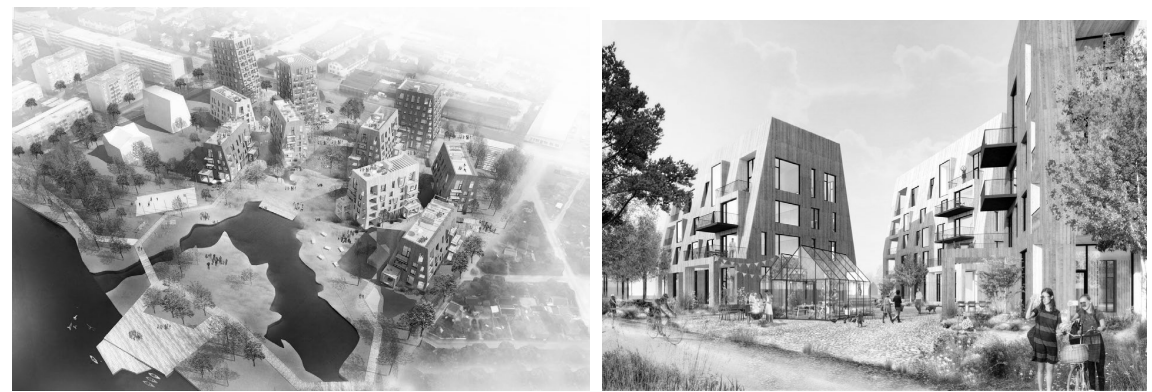

Рис. 1. Екоквартал Timber Town в м. Еребру, Швеція


Рис. 2. Gare De Rungis, еко-квартал, в якому повністю закритий доступ транспорту у двори (Париж)

- використання сучасних «зелених» розробок, а саме системи збору дощової води, вітрогенератори, сонячні батареї;

- обмеження в'їзду на машинах у квартал, перевага пішохідного руху, дозволяється в 'їзд тільки електромобілів;

- наявність впорядкованої системи управління відходами, сортування та переробка сміття.

В ході дослідження виявлено відмінності в підходах до проектування екокварталів та особливості їх в різних країнах [6]. Так Німеччина, скандинавські країни та Великобританія $є$ піонерами в цій галузі, проектування в цих країнах відрізняється системним вирішенням екологічних та соціальних завдань житлового будівництва. Франція довгий час відставала, але зараз темпи реалізації екокварталів перевищують всі країни, в реалізації на даний момент знаходиться близько 200 екокварталів в Парижі, Тулузі та інших містах [1-3]. В італійському будівництві екоквартали зв'язуються лише 3 вирішенням 
екологічних програм, а в Греції будівництво екокварталів направлено на вирішення проблеми доступного соціального житла [6,7]. У Німеччині та Франції обмежується поверховість будівництва до 6 поверхів. А при підвищенні поверховості будівлі, організовуються зелені тераси, балкони та дахи.

Аналіз зарубіжного досвіду дозволив також зробити висновки:

- більша частина реалізованих кварталів знаходиться на периферії міст поблизу природного оточення (лісів і водойм), формування екокварталів в центрах міст поки є поодинокими випадками;

- розміри території екокварталів варіюються від 3 до 40 га;

- застосовуються різноманітні планувальні рішення кварталів: периметральна забудова, вільна, регулярна, нерегулярна забудова;

- використовується різна типологія житлових будинків, в одному кварталі можуть поєднуватися таунхаузи, висотні будинки, коридорні i секційні будинки, розміщуються апартаменти і студентські гуртожитки;

- 3 точки зору громадського обслуговування в передових країнах в цій області створюються функціонально і соціально самодостатні житлові одиниці, в яких в межах пішохідної доступності розміщуються всі об'єкти повсякденного та епізодичного обслуговування, власне адміністративне управління кварталу, рекреаційні території парків і скверів;

- в кварталах поєднується елітне i доступне соціальне житло, проектується житло для людей з обмеженими можливостями.

В силу важливості теоретичних концепцій сталого розвитку міського середовища як складової екологічних факторів, аналізувалися етапи будівництва екокварталів у світі, а також виявлені методи і критерії оцінки зеленого будівництва.

На 1-етапі (80-х рр. ХХ ст.) - створювалися перші поодинокі екоквартали як невелика група будинків на околиці міста або в сільській місцевості; ініціатори створення - професіонали та експерти в розвитку альтернативних напрямків "зеленого" розвитку і будівництва; для реалізації будівництва організовувалася громада жителів (Австралія, Нідерланди, Німеччина) [6,8, 10].

2-й етап (90-і pp. ХХ ст.) - характеризується створенням зразкових екокварталів, широкомасштабним будівництвом в рамках національних i міжнародних програм, при якому проходила апробація інноваційних екотехнологій (рециркуляція дощової води, використання сонячних батарей, фотоелектричних панель). Зразкові проекти потім використовуються для навчання фахівців i зацікавлених сторін, a також для пропаганди екобудівництва в світі $[6,15]$. 
3-й етап - характеризується появою нового типу екокварталів, заснованих на критеріях якості навколишнього середовища і ідеології сталого розвитку територій. Всі проекти ініціюються на місцевому рівні і поступово виходять за рамки суто екологічних проблем $[6,12,14]$.

На 4-му етапі (2000-і рр.) - проекти екокварталів виходять не тільки на рівень вирішення екологічних проблем, а й соціально-економічних. Масове будівництво екокварталів на місцевому рівні за підтримки на державному рівні. Проекти розглядаються як засіб досягнення соціально-економічної стабільності міста і району, досягнення соціальної активності і згуртованості городян. Мета проектів - поліпшення іміджу міста та місцевої ідентичності, підвищення якості життя городян [6,12,14].

Триває пошук показників оцінки якості екокварталів. Зараз існує кілька моделей оцінки якості екобудівництва: DPL підхід, підхід Med Eco-Quarter, LEED оцінка, HQE Amenagement, One Planet Communties, Концепція Есо Tоwn.

Встановлено, що екобудівництво кварталів передбачає обов'язкове використання екобудинків, особливостями яких $є$ енергонезалежність, зелена інженерна інфраструктура, використання природних компонентів в формоутворення будівель. Виявлено особливості архітектурно-планувальних рішень екобудинків - наявність атріумів і зимових садів, велика кількість скління, врахування впливу вітру, сонця та інсоляції приміщень і дворів. Виявлені особливості екокварталів дозволили уточнити це поняття і виявити сучасні тенденції: - досягнення гармонійної єдності природного, соціального i штучного середовища при проектуванні екокварталів; - досягнення соціальної гармонії та формування соціально достатніх місцевих громад $[11,14]$.

У дослідженні сформульовані принципи екобудівництва і прийоми, які забезпечують формування екокварталів.

Принции природоеквівалентності - забезпечує стабільне і гармонійне існування природного середовища, доречність і доцільність прийнятих рішень щодо втручань до існуючого природного ландшафту. На містобудівній рівні принцип реалізується за допомогою низки прийомів: захист i відновлення природного біорізноманіття, відновлення деградованих природних ландшафтів, проектування садів і парків в житлових утвореннях, взаємозв'язок всіх типів озеленених територій в кварталах між собою, між внутрішньо квартальними та міськими і заміськими озелененими територіями (безперервність озеленення); відсутність кордонів і розривів між озелененими територіями; підвищення щільності озеленення в балансі всіх територій житлового району і кварталу; використання властивостей рельєфу, природних водозбірних басейнів і водойм i т.д., тобто проектуванням за законами природного формоутворення. На об'єктному рівні принцип реалізується використанням прийомів зеленої i 
земляної архітектури, озелененням дахів і фасадів будівель, впровадженням озеленення в інтер'єри будівель, облаштуванням зимових садів і озеленених атріумів.

Принцип біорегіоналізму забезпечує збереження культурної ідентичності регіону і міста. На містобудівному рівні принцип реалізується в наступних прийомах: відродження місцевої самобутності і розвиток місцевих мистецтв; створення біорегіональних економік, що підтримують справедливу зайнятість, інклюзивні громади i міжнародні економічні відносини; прагнення до соціокультурної самодостатності населення кварталу. На об'єктному рівні принцип досягається: розміщенням в структурі кварталів і районів будівель культури, що підтримують і розвивають місцеву культуру; індивідуальністю архітектурного образу кварталу і будинків тощо; відповідністю всіх елементів ландшафтно-планувальної організації кварталу клімату i регіональним особливостям місцевої народної культури; використанням місцевих природних матеріалів при будівництві; використанням регіональної та національної символіки в архітектурі; участю жителів в проектуванні і формуванні кварталу (партисіпація); збереженням цінних існуючих елементів озеленення i благоустрою, будівель і споруд, пам'яток архітектури на території району.

Принции соціальної справедливості забезпечує соціальну рівність жителів та рівну доступність природних і антропогенних ресурсів для всіх мешканців. На містобудівній рівні принцип забезпечується наступними прийомами: забезпеченням соціального розмаїття людей в кварталах; доступністю ресурсів для всіх жителів, в тому числі для людей 3 особливими потребами та обмеженими можливостями; відсутністю закритих територій; формуванням повної мережі культурно-побутового обслуговування мешканців в межах кварталу; пішохідною доступністю до об'єктів обслуговування, місць прикладання праці, озеленених територій і т.д. На об'єктному рівні принцип забезпечується наступними прийомами: різноманітністю типів житла i типів будівель обслуговування; будівництвом доступного і соціального житла.

Принции екологічності забезпечує стабільний розвиток створюваного штучного середовища, його енергонезалежність i екологічну валідність прийнятих рішень. На містобудівному рівні принцип реалізується в наступних прийомах: досягненням нульового вуглецю у викидах i виробництві; досягненням нульових відходів у виробництві i побуті; використанням екологічних матеріалів для будівництва і вторинним використанням відходів; використанням відновлюваних технологій; використанням дощової води, очищенням вод в районі, циклічне використання води; використанням стійкого i екологічних видів транспорту; обмеженням автомобільного транспорту в районі. На об'єктному рівні принцип реалізується в наступних прийомах: 
використання різних екобудівель (енергоефективні, пасивні і т.д. будівлі); використання альтернативних джерел енергії; озеленення фасадів, дахів i інтер'єрів будівель; використання дощової води, очищення вод в будівлях; використання природного компонента земля як утеплювача та інші прийоми земляної архітектури.

Висновки. Стан наукових досліджень проблеми формування екокварталів вимагає вивчення i узагальнення сучасного досвіду їх проектування, в тому числі на деградованих територіях найбільших міст.

Виявлено етапи проектування та будівництва екокварталів в світі i визначена сучасна тенденція їх комплексного формування 3 урахуванням вирішення екологічних, функціональних i соціально-культурних завдань. Найважливішими передумовами проектування екокварталів $є$ розвиток моделей оцінки якості екобудівництва і розробка їх критеріїв.

Виявлено особливості екокварталів, що дало можливість уточнити поняття екокварталів. Особливості екокварталів полягають в дотриманні прийомів екобудівництва на містобудівній і об'єктному рівні: використанні зеленої інженерної інфраструктури в будівлі і на територіях, використанні екобудівель, переважанні пішохідного руху і пріоритеті екологічних видів транспорту, функціональній і соціальній самодостатності.

Встановлено, що формування житлових екокварталів має виконуватися 3 використанням наступних принципів: природоеквівалентності, біорізноманіття, соціальної справедливості та екологічності.

\section{Література}

1. Ольга Мочалова, Жюстин Дешамбр. Реновация жилых кварталов. Пример Франции. (Електронний ресурс). - $\quad$ Режим доступу: http://zvt.abok.ru/articles/441/Renovatsiya_zhilih kvartalov Primer Frantsii Дата звернення 8.11.2019.

2. Эко-кварталы процветают во Франции. (Електронний ресурс). - Режим доступу: https://moydom.media/other/eko-kvartaly-procvetaut-vo-francii-174. Дата звернення 10.12.2017.

3. Продвинутый парижский эко-квартал. (Електронний ресурс). - Режим доступу: https://tuexpert.com.ua/prodvinutyy-parizhskiy-eko-kvartal. - Дата звернення 8.12.2019.

4. Экоквартал в Стокгольме. (Електронний ресурс). - Режим доступу: https://www.tourister.ru/world/europe/sweden/city/stockholm/photoreps/1385. Дата звернення 1.12.2019. 
5. Эко-кварталы Швейцарии: города будущего. (Електронний ресурс). Режим доступу: https://cheaptrip.livejournal.com/22078255.html. - Дата звернення 1.12.2019.

6. Stella Kyvelou, Maria Sinou, Isabelle Baer and Toni Papadopoulos. Developing a South-European Eco-Quarter Design and Assessment Tool Based on the Concept of Territorial Capital// INTECH - chapter 24 - p 561-588.

7. Kyvelou, S. \& Papadopoulos T. (2010). Exploring a South-European econeighbourhood model: Planning forms, constraints of implementation and emerging resilience practices// International Journal of Environment and Sustainable Development - Vol. 14 - Nos. 1/2, 2011-pp. 77- 94.

8. Тетиор А. Н. Экокварталы в городе // Промышленное и гражданское строительство. - 1996. - № 9. - С. 23.

9. Тетиор А. Н. Здоровые города XXI века // Промышленное и гражданское строительство. - 1999. - № 1. - С. 45.

10. Barton H., (Ed.). The Potential for Eco Neighbourhoods. - Earthscan Publications Ltd, London, 2000.

11. Barton H.; Grant M. \& Guise R. Shaping Neighbourhoods, for local health and global sustainability. - Routledge, London and New York, 2010.

12. Cities Going Green: A Handbook of Best Practices/ Edited by Roger L. Kemp, Carl J. Stephani. - McFarland \& Company, 2014. - 251p.

13. V. Echarri, C.A. Brebbia. Eco-Architecture VI: Harmonisation between Architecture and Nature. - WIT Press, 2016. - 292 p.

14. Hugh Barton. Sustainable Communities: The Potential for Econeighbourhoods. Earthscan, 2000. - 305 p.

15. Dimitra Babalis. Urban design. The ecological thinking. A compendium. Alinea Editrice, 2008. - 72 p.

д. арх., професор Осыченко Г.А., Харьковский национальный университет городского хозяйства имени А.Н. Бекетова

\section{ОСОБЕННОСТИ ПРОЕКТИРОВАНИЯ ЭКОКВАРТАЛОВ}

В статье рассмотрен зарубежный опыт формирования екокварталов, выявлены этапы развития теорий и практики формирования екокварталов, определены особенности и принципы проектирования экокварталов: принцип природоэквивалентности, биорегионализма, социальной справедливости и экологичности.

Ключевые слова: экокварталы, зеленые города, экоздания, принципы 
проектирования.

Doctor of Architecture, Professor Halyna Osychenko, O.M. Beketov National University of Urban Economy in Kharkiv

\section{FEATURES OF ECOQUARTERS DESIGN}

The relevance of the study also determines: the need for renovation of degraded landscapes of major cities in the territories of former industrial enterprises; lack of study of current trends in the formation of eco-quarters, lack of research and practice of building them in the territory of Ukraine; the need to study the patterns of formation of eco-quarters and approbation of positive foreign experience in Ukraine. Features of designing eco-quarters were identified: use of ecological materials and methods exclusively; use of modern "green" developments, namely rainwater collection systems, wind generators, solar panels; restriction of entry into cars in the quarter, advantage of pedestrian traffic, only electric cars are allowed to enter; having an orderly waste management system, sorting and recycling. It is established that the design of residential eco-quarters should be carried out using the following principles: nature equivalence (stable and harmonious existence of the natural environment, relevance and appropriateness of the decisions taken to intervene in the existing natural landscape); biodiversity (preserving the cultural identity of the region and the city), social justice (social equality of inhabitants and equal access to natural and anthropogenic resources for all residents) and ecological compatibility (energy independence of buildings and ecological validity of urban planning decisions).

Keywords: eco-quarters, green cities, eco-buildings, design principles.

\section{REFERENCES}

1. Olga Mochalova, Zhyustin Deshambr. Renovaciya zhilyh kvartalov. Primer Francii. (Elektronnij resurs). - Rezhim dostupu: http://zvt.abok.ru/articles/441/Renovatsiya_zhilih_kvartalov_Primer_Frantsii - Data zvernennya 8.11.2019.

2. Eko-kvartaly procvetayut vo Francii. (Elektronnij resurs). - Rezhim dostupu: https://moydom.media/other/eko-kvartaly-procvetaut-vo-francii-174. - Data zvernennya 10.12 .2017 .

3. Prodvinutyj parizhskij eko-kvartal. (Elektronnij resurs). - Rezhim dostupu: https://tuexpert.com.ua/prodvinutyy-parizhskiy-eko-kvartal. - Data zvernennya 8.12.2019.

4. Ekokvartal v Stokgolme. (Elektronnij resurs). - Rezhim dostupu: https://www.tourister.ru/world/europe/sweden/city/stockholm/photoreps/1385. - Data 
zvernennya 1.12.2019.

5. Eko-kvartaly Shvejcarii: goroda budushego. (Elektronnij resurs). Rezhim dostupu: https://cheaptrip.livejournal.com/22078255.html. - Data zvernennya 1.12.2019.

6. Stella Kyvelou, Maria Sinou, Isabelle Baer and Toni Papadopoulos. Developing a South-European Eco-Quarter Design and Assessment Tool Based on the Concept of Territorial Capital// INTECH - chapter 24 - p 561-588.

7. Kyvelou, S. \& Papadopoulos T. (2010). Exploring a South-European eco-neighbourhood model: Planning forms, constraints of implementation and emerging resilience practices// International Journal of Environment and Sustainable Development - Vol. 14 - Nos. 1/2, 2011-pp. 77- 94.

8. Tetior A. N. Ekokvartaly v gorode // Promyshlennoe i grazhdanskoe stroitelstvo. - 1996. - № 9. - S. 23.

9. Tetior A. N. Zdorovye goroda XXI veka // Promyshlennoe i grazhdanskoe stroitelstvo. - 1999. - № 1. - S. 45.

10. Barton H., (Ed.). The Potential for Eco Neighbourhoods. - Earthscan Publications Ltd, London, 2000.

11. Barton H.; Grant M. \& Guise R. Shaping Neighbourhoods, for local health and global sustainability. - Routledge, London and New York, 2010.

12. Cities Going Green: A Handbook of Best Practices/ Edited by Roger L. Kemp, Carl J. Stephani. - McFarland \& Company, 2014. - 251p.

13. V. Echarri, C. A. Brebbia. Eco-Architecture VI: Harmonisation between Architecture and Nature. - WIT Press, 2016. - 292 p.

14. Hugh Barton. Sustainable Communities: The Potential for Econeighbourhoods. Earthscan, 2000. - 305 p.

15. Dimitra Babalis. Urban design. The ecological thinking. A compendium. Alinea Editrice, 2008. - 72 p. 